American Journal of Agricultural and Biological Sciences 6 (1): 162-171, 2011

ISSN 1557-4989

(C) 2010 Science Publications

\title{
Effect of Edible Coatings, Storage Time and Maturity Stage on Overall Quality of Tomato Fruits
}

\author{
Jorge Esteban de Jesús Dávila-Aviña, José Villa-Rodríguez, Reynaldo Cruz-Valenzuela, \\ Mariana Rodríguez-Armenta, Miguel Espino-Díaz, Jesús Fernando Ayala-Zavala, \\ Guadalupe Isela Olivas-Orozco, Basilio Heredia and Gustavo González-Aguilar \\ Research Center for Food and Development, AC Km 0.6, Road to Victory, \\ P.O. Box 1735, Hermosillo, Sonora, 83000, México
}

\begin{abstract}
Problem statement: Tomato (Lycopersicon esculentum Mill.) is one of the most widely consumed fresh vegetables in the world; however, its highly perishable nature limits its postharvest life. Major losses in tomato quality and quantity occur between harvest and consumption. Therefore, the application of new technologies to extend the postharvest life of this commodity is needed. The use of edible coatings appears to be a good alternative. Approach: We evaluated the effect of carnauba and mineral oil coatings on the postharvest quality of tomato fruits (cv. "Grandela"). Stafresh $2505^{\mathrm{TM}}$ (carnauba) and Stafresh $151^{\mathrm{TM}}$ (mineral oil) coatings were applied on fresh tomatoes at two maturity stages (breaker and pink). The quality of tomatoes was evaluated periodically at $0,5,10,15,21$ and 28 days of storage at $10^{\circ} \mathrm{C}$, plus 2 days at $20^{\circ} \mathrm{C}$. For respiration rate analysis, tomatoes were kept at $20^{\circ} \mathrm{C}$ for 16 days. Results: At the beginning of the study, $\mathrm{CO}_{2}$ production was reduced by 38 and $46 \%$ when applying the mineral oil coating on breaker and pink tomatoes, respectively. In addition, early during the study, the mineral oil coating showed suppression of ethylene biosynthesis at both maturity stages. Both coatings reduced $30 \% \mathrm{PG}$ activity of tomato tissue. At the end of storage, mineral oil coatings delayed color changes and reduced weight losses for up 70 and $46 \%$ at the breaker and pink stages, respectively. Conclusion/Recommendations: Respiration rate, color, weight loss and enzyme activity were positively affected by mineral oil coating at both maturity stages. No effects on firmness, titratable acidity and $\mathrm{pH}$ were found by the coating application. We concluded that mineral oil coating could be a good alternative to preserve the quality and extend the postharvest life of tomato fruit.
\end{abstract}

Key words: Edible coatings, postharvest quality, pectin methyl esterase, polygalacturonase, Lycopersicon esculentum mill

\section{INTRODUCTION}

Consumers judge the quality of fresh tomatoes by their firmness, color and taste, which are related to ripeness and shelf life. Major losses in the quality and quantity of fresh vegetable and fruit products occur between harvest and consumption (Brooks et al., 2008). These are critically dependent upon three factors: (1) reduction in desiccation, (2) reduction in the physiological process of maturation and senescence and (3) reduction in the onset and rate of microbial growth. The perishability of tomatoes requires the development of technologies that reduce their postharvest deterioration and extend their shelf life (GonzalezAguilar et al., 2009).

The use of edible coatings in conjunction with lowtemperature storage appears to be a promising approach to minimize these problems and preserve the freshness of tomatoes (Gonzalez-Aguilar et al., 2010a). The mechanism by which edible coatings preserve fruits and vegetables is the establishment of a modified atmosphere around the product, which serves as a partial barrier to $\mathrm{O}_{2}$ and $\mathrm{CO}_{2}$, water vapor and aroma compounds, decreasing the respiration rate of the fruit and water loss and preserving texture and flavor (Olivas and BarbosaCanovas, 2008). In addition to the use of edible coatings, food additives can be added to plant foods to control detrimental reactions (Rojas-Graü et al., 2009).

Edible coatings are composed of hydrocolloids (polysaccharides or proteins), hydrophobic compounds (lipids or waxes) or a combination of both (composite coatings) that may enhance the coating properties for optimal handling (Espino-Diaz et al., 2010). Several

Corresponding Author: G.A. González-Aguilar, Department of Vegetable Food Technology, Research Center for Food Research and Development, CIAD, AC, Km 0.6 Road to Victory, P.O. Box 1735, Hermosillo, Sonora, 83000, México Tel/Fax: +52(662) 2892400 ext. 272. e-mail:gustavo@ciad.mx. 
studies have reported the use of edible coatings for fruit and vegetable preservation during storage. Today, many edible coatings are available, mainly to preserve the quality of citrus and apples and to a lesser extent, mangos, papayas, pomegranates, cherries, avocados, cantaloupes and tomatoes, among others (Olivas et al., 2008). Given the perishability of tomato and its importance in world agricultural trade, the purpose of the present study was to determine the effect of two types of commercial coatings on tomato fruit quality during storage.

\section{MATERIALS AND METHODS}

Plant material: Fresh tomato fruits (cv. "Grandela") were greenhouse-produced in Obregón, Sonora, Northwest México. Upon arrival, the fruits were selected based on their size, weight, color and external appearance. Samples were washed using chlorinated water (200 ppm) for $2 \mathrm{~min}$ and then left to dry at room temperature for about $1 \mathrm{~h}$. Fruit samples were classified according to their size, uniformity and maturity stage (2 and 4). At stage 2 (i.e., "breaker"), fruits showed less than $10 \%$ green color, while at stage 4 (i.e., "pink"), fruits showed a color other than green on less than 30$60 \%$ of the surface of the whole fruit (Sargent et al., 2005).

Edible coatings: Commercial carnauba-based Stafresh $2505^{\mathrm{TM}}$ (SF 2505) and mineral oil-based Stafresh $151^{\mathrm{TM}}$ (SF 151) coatings were provided by FMC Foodtech (Riverside, CA).

Treatments: Fruits were divided into two batches based on subjective evaluations. In both batches, fruits classified as being stage 2 and 4 mature were subdivided into three groups (control, mineral oil and carnauba). For each maturity stage, carnauba and mineral oil edible coatings at $1 \mathrm{l} /$ ton were manually applied using Artex ${ }^{\mathrm{MR}}$ brushes S-1110 (México). One hundred eighty fruits per maturity stage (60 fruits per treatment) were used and stored at $10^{\circ} \mathrm{C}$. For the first batch, external color, weight loss, firmness, titratable acidity, Total Soluble Solids (TSS), Polygalacturonase (PG) and Pectin Methyl Esterase (PME) were recorded on days $0,5,10,15,21$ and 28 of storage. Additionally, at each sampling date, 3 fruits were transferred to $20^{\circ} \mathrm{C}$ for 2 days (simulating marketing conditions) for the evaluation of color change, firmness and weight loss. For the second batch, 24 fruits were stored at $20^{\circ} \mathrm{C}$ to evaluate the respiration rate $\left(\mathrm{CO}_{2}\right.$ and ethylene production) at $0,1,2,3,4,6,8,9,13$ and 16 days

Physiological and chemical analysis: The respiration rate was measured by placing individual fruits in 1.8-1 hermetically sealed plastic containers. After $1 \mathrm{~h}, 1-\mathrm{mL}$ headspace samples were taken using a hypodermic needle and injected into a Varian Star 3400 CX gas chromatograph (Varian, DF, México) equipped with a Haysep N column (200, 3 mm ID; $80100 \mu \mathrm{m}^{-1}$ particle size). A thermal conductivity detector and a flame ionization detector were used for carbon dioxide $\left(\mathrm{CO}_{2}\right)$ and ethylene $\left(\mathrm{C}_{2} \mathrm{H}_{4}\right)$ evaluation, respectively. The temperature was set to $50^{\circ} \mathrm{C}$ for the column, $70^{\circ} \mathrm{C}$ for the injector, $170^{\circ} \mathrm{C}$ for the TCD detector and $205^{\circ} \mathrm{C}$ for the FID detector. The concentration of each gas was calculated by determining the area under the curve and the value was compared with that of known standards. The results were recorded as $\mathrm{mL} \mathrm{CO}_{2} \mathrm{Kg} \mathrm{h}^{-1}$ and $\mu \mathrm{L}$ $\mathrm{C}_{2} \mathrm{H}_{4} / \mathrm{Kg}$-h. External color was determined from three points of equatorial area from 10 fruit per treatment using a Minolta colorimeter (model CR-300; Minolta corp., Ramsey, NJ, USA). The values were obtained on a CIELAB scale $\left(L^{*}, a^{*}, b^{*}\right)$ and hue angle and chroma values were calculated. The $L^{*}$ value represents the luminosity of the fruit, where $0=$ black and $100=$ white. The $a^{*}$ value ranges from a negative (green) to a positive (red) scale. The $b^{*}$ value can range from being negative (blue) to being positive (yellow). To obtain the real color changes of the fruit, $a^{*}$ and $b^{*}$ values were used to calculate the hue angle $\left({ }^{\circ} \mathrm{Hue}\right)$ and the chroma (intensity) value with the following equation:

${ }^{\circ} \mathrm{Hue}=\operatorname{arctg} \mathrm{b}^{*} / \mathrm{a}^{*}$

$\mathrm{C}=\left[\left(\mathrm{a}^{*}\right)^{2}+\left(\mathrm{b}^{*}\right)^{2}\right]^{1 / 2}$

Where:

${ }^{\circ} \mathrm{Hue}=0$ represents Purple-Red

$90^{\circ}=$ Yellow

$180^{\circ}=$ Green-blue

$270^{\circ}=$ Blue

(Pek et al., 2010)

Weight loss was determined according to the initial weight, measured using a digital balance (Mettler Toledo, New York, NY, USA) and the results were reported as weight loss percentage. Regarding tomato firmness, this parameter was measured by a puncture method using a Chatillon Penetrometer DFM50 (Ametek, Largo, FL, USA) with an 8-mm diameter flathead stainless-steel cylindrical probe. The tissue's opposing force against the penetration was registered on 3 points in the equatorial region of the fruit and the results were reported in Newton's $(\mathrm{N})$.

The $\mathrm{pH}$, Titratable Acidity (TA) and Total Soluble Solids (TSS) were determined as previously described by Islas-Osuna et al. (2010), with slight modifications. Briefly, $10 \mathrm{~g}$ of tomato was homogenized in $50 \mathrm{~mL}$ of 
distilled water. Then, the mixture was filtered using organza fabric. An aliquot of $50 \mathrm{~mL}$ was used to quantify the $\mathrm{pH}$ and TA using a DL21 automatic Titrator (MettlerToledo, USA). The TA was expressed as a percentage of citric acid. TSS were measured directly from the filtered residue using an Abbe digital refractometer and expressed as degree Brix.

Enzyme assays: Polygalacturonase (PG) activity was determined following the method described by Gayosso-Garcia et al. (2010). A 10-g sample was homogenized in an Ultra Turrax ${ }^{\circledR}$ T25 with $20 \mathrm{~mL}$ of $1 \%$ sodium bisulfite buffer $\mathrm{pH} 6.0$; then, it was filtered and the residue was washed with $20 \mathrm{~mL}$ of $1 \%$ sodium bisulfite, followed by another wash with $15 \mathrm{~mL}$ of $1 \mathrm{M}$ $\mathrm{NaCl}$. The extract's $\mathrm{pH}$ was adjusted to 6.0 and the extract was then stirred continuously for $3 \mathrm{~h}$ in a Thermolyne Speci-Mix agitator at $4^{\circ} \mathrm{C}$. The sample was then filtered and centrifuged at $9400 \times \mathrm{g}$ at $4^{\circ} \mathrm{C}$ for 15 min. An enzyme solution $(250 \mu \mathrm{L})$ was mixed well with a substrate solution ( $2 \mathrm{mg}$ polygalacturonic acid dissolved in $750 \mu \mathrm{L}$ of sodium acetate buffer $37.5 \mu \mathrm{M}$, $\mathrm{pH} 4.4$ ) and incubated in a water bath at $30^{\circ} \mathrm{C}$ for $2 \mathrm{~h}$. The extract was centrifuged at $9400 \times \mathrm{g}$ at $4^{\circ} \mathrm{C}$ for 15 min and $200 \mu \mathrm{L}$ of the supernatant was taken and mixed with $1 \mathrm{~mL}$ of $0.1 \mathrm{M}$ borate buffer at $9.0 \mathrm{pH}$ with $200 \mu \mathrm{L}$ cyanoacetamide (1\%). The mixture was placed in a water bath at $100^{\circ} \mathrm{C}$ for $10 \mathrm{~min}$ and was left to cool at room temperature. The absorbance was recorded using an UV-VIS VARIAN CARY 50 BIO spectrophotometer set at a wavelength of $276 \mathrm{~nm}$. Galacturonic acid was used to prepare a standard curve (0-100 nmoles) for the PG activity assay. The PG activity was expressed as Unit $\mathrm{mg} \mathrm{FW}^{1}$, where one activity unit was defined as the amount of enzyme that releases $1 \mathrm{nmol}$ of reducing groups per $1 \mathrm{~h}$. The assay was conducted three times for each RS. To measure Pectin Methyl Esterase (PME) activity, a $10 \mathrm{~g}$ fruit sample was homogenized with $25 \mathrm{~mL}$ of Tris-Cl $0.1 \mathrm{M}$ buffer at $\mathrm{pH} 8.0$ containing $0.3 \mathrm{M} \mathrm{NaCl}$ in an Ultra Turrax $^{\circledR}$ T25. Samples were placed in a Thermolyne Speci-Mix agitator at $4^{\circ} \mathrm{C}$ for $30 \mathrm{~min}$, followed by centrifugation at $9400 \times \mathrm{g}$ for $25 \mathrm{~min}$ at $4^{\circ} \mathrm{C}$. The enzymatic extract was stored at $-35^{\circ} \mathrm{C}$ until analysis and PME was determined as previously described by Gayosso-Garcia et al. (2010). This method consists of enzyme activity evaluation by titration, using $25 \mathrm{~mL}$ of $1 \%$ pectin in $0.1 \mathrm{~N} \mathrm{NaCl}$ at $7.5 \mathrm{pH}$ as a substrate, which was adjusted with $0.1 \mathrm{~N} \mathrm{NaOH}$. The pectin was placed in a water bath at $30^{\circ} \mathrm{C}$ for $10 \mathrm{~min}$ and $2 \mathrm{~mL}$ of the extract was added. The decrease in $\mathrm{pH}$ caused by the carboxylic groups, generated by the PME during the deesterification of the pectin solution, was held constant at a $\mathrm{pH}$ of 7.5 by titrating the solution with $0.049 \mathrm{~N}$ $\mathrm{NaOH}$ for $10 \mathrm{~min}$ at $24^{\circ} \mathrm{C}$. The titration was performed with a DL21 automatic titrator (Mettler-Toledo, Columbus, OH, USA). The results were expressed as units of PME activity, where one unit is defined as the amount of enzyme required to hydrolyze $1 \mu \mathrm{mol}$ of carboxyl groups per $1 \mathrm{~mL}$ of pectin substrate per minute.

Ethanol and acetaldehyde determination was performed using methods previously described by Gonzalez-Aguilar et al. (2004). A sample with a mass of $10 \mathrm{~g}$ was placed in 20-mL container and incubated in a water bath (Precision Scientific, Chicago, IL, USA) at $70^{\circ} \mathrm{C}$ for $15 \mathrm{~min}$. One-milliliter headspace samples were injected into a Varian Star $3400 \mathrm{CX}$ gas chromatograph (Varian, DF, México equipped with a 2 $\mathrm{m} \times 1 / 8$-inch Chromosorb stainless steel column, packed with 80/100 Am mesh Porapack 101). Ethanol and acetaldehyde in water solution were used as standards for peak identification and quantification.

Statistical analysis: The data were analyzed using the GLM procedure of the Number Cruncher Statistical System version 6.0 software (NCSS, LLC). The differences between treatments were determined using Tukey's multiple range test at a significant level of $\mathrm{p} \leq 0.05$.

\section{RESULTS}

Respiration rate $\left(\mathrm{CO}_{2}\right.$ and $\mathrm{C}_{2} \mathrm{H}_{4}$ production): Significant differences $(\mathrm{p}<0.05)$ in the respiration rate of $\mathrm{CO}_{2}$ and $\mathrm{C}_{2} \mathrm{H}_{4}$ production of tomato fruits were observed between treatments and storage days of tomatoes at both maturity stages (Fig. 1). Control and coated fruits showed an initial $\mathrm{CO}_{2}$ production rate of 33.4, 20.7 and $28.5 \mathrm{~mL} \mathrm{Kg} \mathrm{h}^{-1}$ for the breaker stage and $31.5,17.0$ and $25.6 \mathrm{~mL} \mathrm{Kg} \mathrm{h}^{-1}$ for the pink stage, respectively. For both maturity stages, the respiration rate remained relatively constant during the storage period.

The results of ethylene production for the control, SF 151 and SF 2505 tomatoes were 3.61, 0 and $3.68 \mu \mathrm{L}$ $\mathrm{Kg} \mathrm{h}^{-1}$ and 2.6, 0 and $3.9 \mu \mathrm{L} \mathrm{Kg} \mathrm{h}^{-1}$ for pink tomatoes, respectively (Fig. 1). The control and SF 2505-treated samples showed an increase in ethylene production after the first day of storage at $20^{\circ} \mathrm{C}$, a condition related to the climacteric peak of tomatoes. The highest ethylene production was observed on day 2 of storage with 5.7 and $8.0 \mu \mathrm{L} \mathrm{Kg} \mathrm{h}^{-1}$ for breaker and pink tomatoes, respectively. The lowest ethylene production was observed on day 9 for breaker and pink tomatoes treated with SF 151 edible coating, exhibiting 2.1 and $1.3 \mu \mathrm{L} \mathrm{Kg} \mathrm{h}^{-1}$, respectively. 


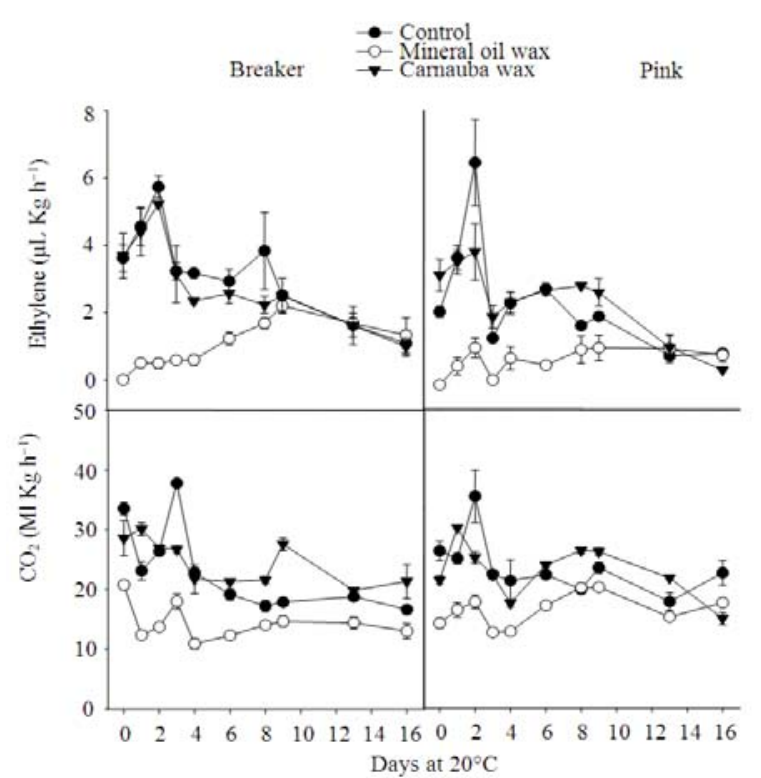

Fig. 1: $\mathrm{CO}_{2} \quad(\mathrm{~mL} / \mathrm{Kg} . \mathrm{h})$ and ethylene ( $\left.\mu \mathrm{L} / \mathrm{Kg} . \mathrm{h}\right)$ production of tomato fruits (cv. "Grandela") at pink and breaker maturity stages treated with mineral oil and carnauba wax and stored for 16 days at $20^{\circ} \mathrm{C}$. Each value is the mean of 4 measurements $\pm \mathrm{SE}$.

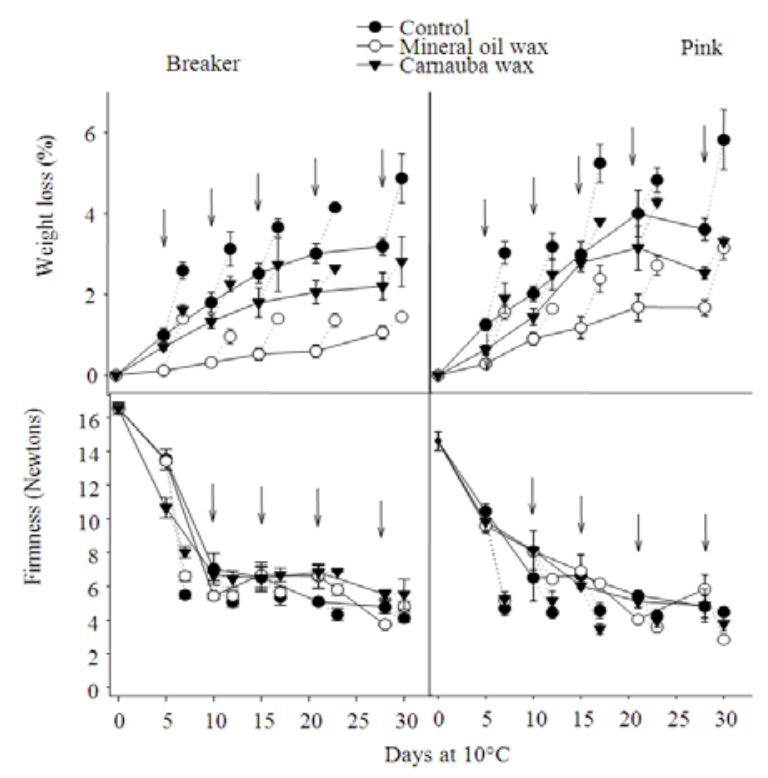

Fig. 2: Weight loss (\%) and firmness $(\mathrm{N})$ of tomato fruits (cv. "Grandela") at pink and breaker maturity stages treated with mineral and carnauba wax and stored for 28 days at $10^{\circ} \mathrm{C}$. The arrows indicate the times at which the fruits were transferred to $20^{\circ} \mathrm{C}$ for 2 days for evaluation
Weight loss: The weight loss (\%) and firmness (N) offresh tomatoes during storage at $10^{\circ} \mathrm{C}$ plus 2 days at $20^{\circ} \mathrm{C}$ are shown in Fig. 2. The weight loss of the tomatoes increased with the storage period, which was higher for the control and SF 2505-treated fruits, followed by the weight loss of the SF 151 samples $(p<0.05)$. The weight loss of the control, SF 151 and SF 2505 samples at the breaker stage continued to increase until they reached values of $3.19 \%, 1.6$ and $2.20 \%$, whereas the weight loss of the same sample treatments at the pink stage showed a weight loss of $3.76,1.67$ and $2.53 \%$, after 28 days of storage at $10^{\circ} \mathrm{C}$, respectively. Breaker tomatoes that were transferred to $20^{\circ} \mathrm{C}$ showed a similar trend. Control tomatoes lost approximately $4.87 \%$ of their weight, whereas tomatoes with SF 151 and SF 2505 coatings lost 1.44 and $2.81 \%$ of their weight, respectively. After transferring the fruit to $20^{\circ} \mathrm{C}$ for 2 days, the weight loss of the pink tomatoes was significantly higher than that of the breaker tomatoes $(\mathrm{p}<0.05)$. The control, SF 2505- and SF 151-treated fruits lost 5.82, 3.15 and $3.30 \%$ of their original weight, respectively.

Firmness: Edible coatings significantly $(p<0.05)$ reduced the weight and firmness losses of tomato at both maturity stages (Fig. 2). Initially, the breaker and pink samples had similar firmness $(15-16 \mathrm{~N})$. Then, a decrease in that of the breaker fruits of 7.73, 5.43 and $7.03 \mathrm{~N}$ and in the pink fruits of $6.5,8.08$ and $8.13 \mathrm{~N}$, was observed for the control, SF 151 and SF 2505 treated samples, respectively. Fruit firmness decreased continuously for all treatments, reaching similar values ranging from 3.77$5.83 \mathrm{~N}$. After transferring the fruit to $20^{\circ} \mathrm{C}$ for 2 days, the firmness decreased, following the same pattern after 30 days of storage.

pH, TA and TSS: The changes in the TA, TSS and pH of the control and coated tomatoes are shown in Fig. 3. In general, fruit acidity tends to decrease with maturation and a concomitant increase in sugar content (Raffo et al., 2002).

The results show significant differences between the effects of the number of days of storage and treatments during both ripening stages. Initially, the breaker and pink tomatoes had a TSS of 4.1 and 4.7, a TA of 0.54 and $0.49 \%$ and a $\mathrm{pH}$ of 4.1 and 4.0 , respectively. The TSS of the breaker tomatoes remained relatively constant during storage, except in the control fruit, which presented a $15 \%$ increase at the end of the experiment. Pink tomatoes showed a decrease in TSS of approximately $15-20 \%$ with respect to the initial ones. In contrast, the TA of the tomatoes decreased with maturity and was not significantly affected $(\mathrm{p}<0.05)$ by coating treatment (Fig. 3). However, the TA of breaker fruits 
Am. J. Agri. \& Biol. Sci., 6 (1): 162-171, 2011

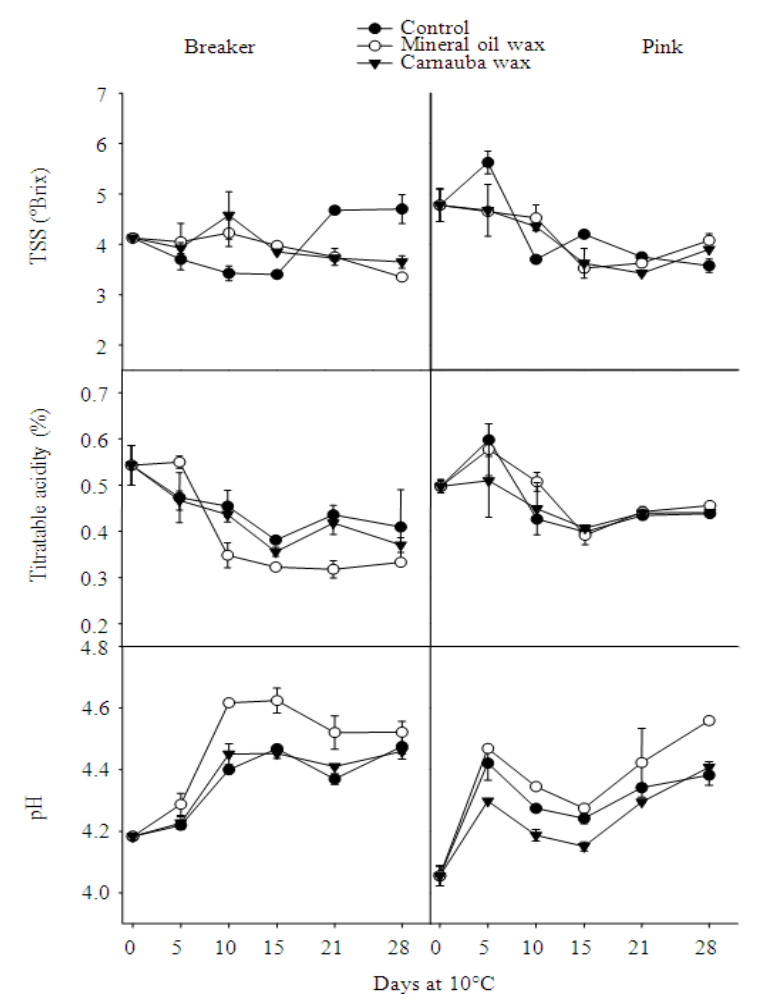

Fig. 3: Titratable acidity (\% citric acid), Total Soluble Solids (TSS ${ }^{\circ}$ Brix) and $\mathrm{pH}$ of tomato fruits (cv. "Grandela") at pink and breaker maturity stages treated with mineral and carnauba wax and stored for 28 days at $10^{\circ} \mathrm{C}$. Each value is the mean of 4 replicates $\pm \mathrm{SE}$

treated with SF 151 and SF 2505 decreased 40 and 25\%, respectively, with respect to the control fruits. The $\mathrm{pH}$ increased with maturity and was higher in SF 151-treated fruits without significant differences compared to other treatments, including control fruits.

The increase in $\mathrm{pH}$ of tomato tissue was less than 0.5 at both maturity stages after 28 days of storage, with respect to that obtained at the beginning of the experiment.

Color attributes: Figure 4 shows the effects of edible coatings and maturity stage on the color attributes $\left(\mathrm{L}^{*}\right.$, ${ }^{\circ} \mathrm{Hue}$ and chroma) of tomato fruits stored at $10^{\circ} \mathrm{C}$. A significant effect $(p<0.05)$ of the edible coatings, storage time and maturity stage on the $L^{*}$ values of tomato fruits was observed. Mineral oil wax (SF 151)treated tomatoes showed the highest $\mathrm{L}^{*}$ values $(\mathrm{p}<0.05)$ as compared to those of carnauba-waxed (SF 2505) and control fruits. However, no significant differences were observed between carnauba-wax-treated and control tomatoes. A decrease in the $\mathrm{L}^{*}$ values of tomato fruits was observed during the storage period, reaching the lowest values at day 28 .

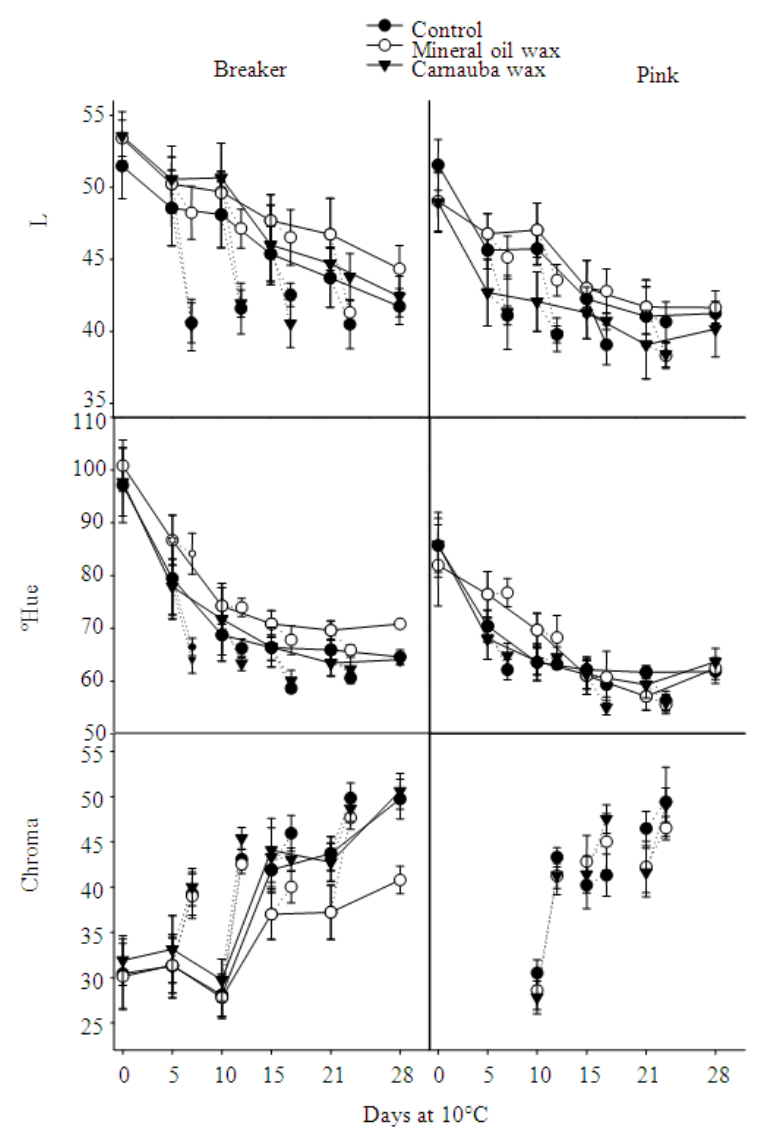

Fig. 4: Chroma, ${ }^{\circ}$ Hue and $\mathrm{L}$ values of tomato fruits (cv. "Grandela") at pink and breaker maturity stages treated with mineral and carnauba wax and stored for 28 days at $10^{\circ} \mathrm{C}$. The arrows indicate the times at which the fruits were transferred to $20^{\circ} \mathrm{C}$ for 2 days for evaluation. Each value is the mean of 30 replicates \pm SE.

The breaker maturity stage showed the highest $\mathrm{L}^{*}$ values as compared to the $L^{*}$ values of the pink tomatoes. The same effects and patterns were observed for the ${ }^{\circ} \mathrm{Hue}$ angle values of coated tomatoes stored at $10^{\circ} \mathrm{C}$. However, a significant effect $(\mathrm{p}<0.05)$ of edible coatings, storage time and maturity stage on the chroma values of tomato fruits was observed. The control and carnauba-waxed tomatoes showed the highest chroma values, without significant differences between them. The lowest chroma values were recorded for mineral oil wax coatings, which were significantly different than those of the control and carnauba-waxed tomatoes. The chroma values increased during the storage period, reaching the highest values at the end of the experiment. Pink tomatoes showed the highest chroma values, which were significantly different to the values observed for 
breaker tomatoes. These results suggest that edible coatings composed of mineral oil wax, delayed to a higher extent, the ripening process of tomato fruits at the breaker and pink maturity stages when stored at $10^{\circ} \mathrm{C}$.

PG and PME analysis: The effects of edible coatings, storage time and maturity stage on the activity of PG and PME enzymes of tomato fruits stored at $10{ }^{\circ} \mathrm{C}$ are shown on Fig. 5. Significant effects $(p<0.05)$ of the storage time and maturity on the activity of PG enzyme were observed; however, no significant effect $(\mathrm{p}=$ 0.315 ) of the edible coating treatment was found. Various increments in PG activity during storage were observed for all samples at every maturity stage. Specifically, pink tomatoes showed higher values of PG activity compared to breaker tomatoes. However, a significant effect $(p<0.05)$ of edible coating treatment, storage time and maturity stage on the activity of PME enzyme was observed. The control tomatoes showed the highest values of PME activity, followed by carnauba and mineral oil waxes, with significant differences $(p<0.05)$ amongst them. Even when the effect of storage time was statistically significant, a random pattern of decrease and increase in PME activity during storage was observed. Therefore, the initial day of the experiments showed the highest PME activity value, followed by a rapid decrement at day 5 , then a slight increase at day 10 and finally, a marked decrease until the end of the storage period, when the lowest PME activity value was observed. The pink maturity stage showed a higher PME activity value compared to the breaker stage.

Off-flavor analysis: Significant effects $(\mathrm{p}<0.05)$ of edible coating treatments, storage time and maturity stage on acetaldehyde content from treated tomato fruits stored at $10^{\circ} \mathrm{C}$ were observed (Fig. 6). Mineral oil wax promoted a higher accumulation of acetaldehyde on treated tomatoes, which was statistically different $(p<0.05)$ from the acetaldehyde contents of carnaubawax-treated and control fruits. No significant differences were observed between carnauba-wax-treated and control tomatoes. Acetaldehyde content of the tomato fruits decreased during the storage period, reaching the lowest contents at the end of the experiment. It was found that the breaker maturity showed higher acetaldehyde content, which was statistically different from that of the pink stage. The same effects and patterns were observed with respect to the ethanol content of tomato fruits stored at $10^{\circ} \mathrm{C}$.

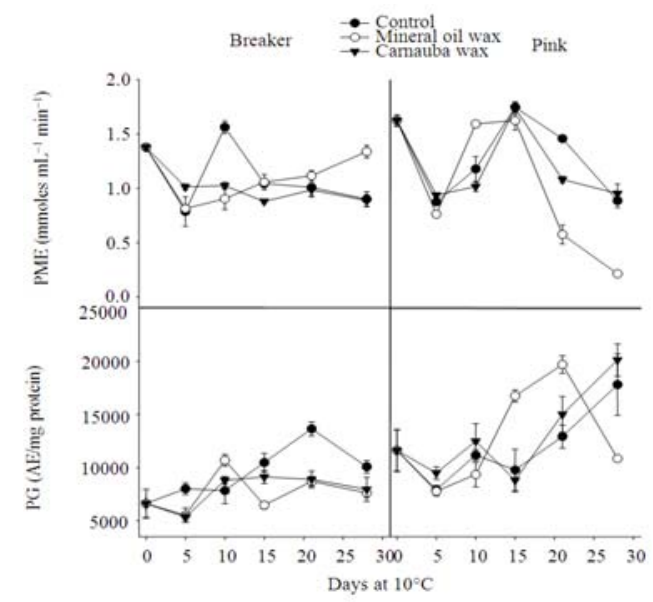

Fig. 5: Enzyme activities of polygalacturonase (AE $\mathrm{mg}^{-1}$ protein) and pectin methyl esterase $\left(\mathrm{mmol} \mathrm{mL} \mathrm{min}^{-1}\right.$ ) of tomato fruits (cv. "Grandela") at pink and breaker maturity stages treated with mineral and carnauba wax and stored for 28 days at $10^{\circ} \mathrm{C}$. Each value is the mean of 6 replicates \pm SE

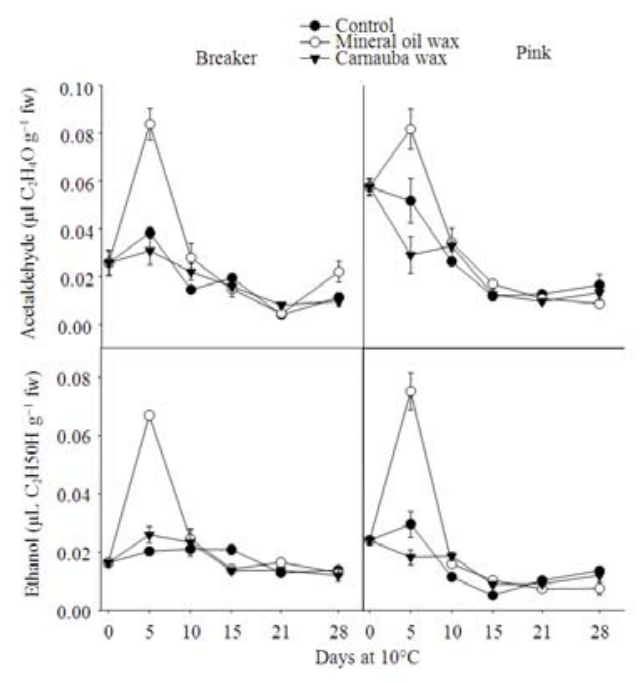

Fig. 6: Ethanol ( $\mu \mathrm{L} \mathrm{C} 2 \mathrm{H} 5 \mathrm{OH} / \mathrm{g} \mathrm{fw})$ and acetaldehyde $\left(\mu \mathrm{L}\right.$ C2 $\left.\mathrm{H} 4 \mathrm{O} \mathrm{g}^{-1} \mathrm{fw}\right)$ production from tomato fruits (cv. "Grandela") at pink and breaker maturity stages that were treated with mineral and carnauba wax and stored for 28 days at $10^{\circ} \mathrm{C}$. Each value is the mean of 6 replicates $\pm \mathrm{SE}$.

\section{DISCUSSION}

Respiration, transpiration and ethylene production are the main factors contributing to the deterioration of fruits and vegetables (Gonzalez-Aguilar et al., 2010b). 
In general, tomatoes treated with SF 151 edible coatings significantly reduced respiration rates during storage. El Ghaouth et al. (1992), reported that chitosan-based coatings reduced the respiration rate and ethylene production of tomatoes. The effects of edible coatings on other critical factors, such as the gas permeation properties of the fruit skin and the possible benefits of internally modified gas composition, have not yet been fully studied. The quality of coated fruits can vary greatly due to the fact that coatings developed for one variety of fruit may not be appropriate for another, as each fruit is different with respect to skin resistance, gas diffusion, fruit respiration rate and other qualities (Espino-Diaz et al., 2010).

A reduction in weight loss has been observed using edible coatings. Chumarrelli and Ferreira (2005) observed a similar trend in the weight loss of noncoated $(3.41 \%)$ fruits and fruits coated with commercial carnauba-based (1.63\%) coatings after 15 days at $12.5^{\circ} \mathrm{C}$. Zhuang et al. (2003), Tasdelen and Bayindirli (1998), Park et al. (1994) and El Ghaouth et al. (1992) concluded that wax application largely contributed to the reduction in the weight losses of tomatoes. Edible coatings act as water-loss barriers, causing high relative humidity in the surrounding atmosphere of the tomato fruit and thus reducing the moisture gradient to the exterior (Olivas et al., 2003). Sargent et al. (2005) reported that tomato fruits are susceptible to water loss, mainly through the stem scar. Shriveling symptoms may become evident when a fruit loses as little as 3\% of its initial weight. In the present study, the treated fruit did not exceed 3\% weight loss, as was previously reported by Sargent et al. (2005). Therefore, no severe symptoms of shriveling were observed during the storage period, especially in coating-treated tomatoes. Texture is a major factor defining the quality of fruit and strongly influences consumer acceptability (Gonzalez-Aguilar et al., 2008). Edible coatings decrease the water vapor transmission rate by forming a barrier around their substrates. This prevents texture reduction, as water is essential for the preservation of cell turgor (Perez-Gago et al., 2010).

In our study, the edible coatings significantly $(p<0.05)$ reduced water and firmness losses in samples at both maturity stages. Our results are similar to those reported by El Ghaouth et al. (1992) on fresh tomatoes coated with chitosan that maintained more firmness than uncoated fruit after 28 days of storage at $20^{\circ} \mathrm{C}$. Batu (2004) reported that the minimum acceptability level or marketability score of tomato firmness at which an individual tomato fruit is acceptable for retail is about 1.45 and $1.46 \mathrm{~N} \mathrm{~mm}^{-1}$. However, once at home, the firmness values of those tomatoes are found to be in a lower range, from 1.22-1.28 $\mathrm{N} \mathrm{mm}^{-1}$ (Batu 2004). In this context, we can consider that coated tomatoes from our research were acceptable for up to 30 days of storage.

Organic acids provide most of the hydrogen ions in tomatoes and normally decrease with ripening, producing an increase in pH. Hernandez et al. (2008a) determined the TSS, TA and $\mathrm{pH}$ of five tomato cultivars, reporting average values of $4.6 \pm 0.9{ }^{\circ}$ Brix, $0.50 \pm 0.09 \mathrm{~g} 100^{-1} \mathrm{~g}$ of citric acid and 4.1 \pm 0.08 , respectively. These parameters are influenced by many factors such as cultivar, cultural practices, region of cultivation and harvest season (Hernandez et al., 2008b).

Tomato fruit ripening is a complex, genetically programmed process that culminates in dramatic changes in the color of the fruit (Alonso et al., 2010). The characteristic red pigmentation of ripe tomato fruit is the result of the de novo synthesis of carotenoids, mainly lycopene and $\beta$-carotene, which are associated with the change in fruit color from green to red as chloroplasts are transformed to chromoplasts (MejiaTorres et al., 2009). However, this process could be delayed to prolong the postharvest life of tomato fruit. One alternative to modify the ripening process is the use of edible coatings. The delay of red color formation of coated tomatoes is related to the modification of the internal atmosphere of the fruit, which produces high $\mathrm{CO}_{2}$ and low $\mathrm{O}_{2}$ levels that affect the maturation process (Zapata et al., 2008). In another study, the color of chitosan-coated tomatoes was subjectively evaluated after 22 days of storage; the study showed that control tomatoes ripen faster than the chitosan-coated fruits, based on the higher red color intensity observed for the chitosan-coated fruits. Waxed and non-waxed mature green tomato fruits were stored at different temperatures $\left(12\right.$ and $\left.5^{\circ} \mathrm{C}\right)$ and their skin color and pigment content were evaluated. Waxed fruits showed a delay in color development and ripening. A delay in chlorophyll degradation and lycopene synthesis was observed as a result of the use of wax and storage at low temperature (Mejia-Torres et al., 2009). In this context, the waxing of the tomato fruits allowed for the delay of the maturation process. Natural changes in chemical composition and acetaldehyde and ethanol content were not affected by the studied coatings.

Polygalacturonase (PG) is considered to be one of the first enzymes found in fruit tissue that is involved in the degradation of cell walls during the maturation process, which is due its capacity to degrade polygalacturonic acid chains, the main components of middle lamella that are also found in primary cell walls (Brummell and Harpster, 2001). PG expression is developmentally regulated through the ethyleneindependent signal transduction pathway, but the 
translatability of PG mRNA or the stability of the PG protein may be ethylene-dependent and PG and PME act to break down pectin, which is critical to tomato texture (Alexander and Grierson, 2002). The effect of chitosan coatings on the PG and PME activities of tomatoes showed a 50\% enzyme activity reduction for all tested enzymes (Reddy et al., 2000). The authors associated the reduction in activity of the texturerelated enzymes with the delay in maturation of the treated fruits. These results are in agreement with our work, in which mineral oil wax showed a more significant $(\mathrm{p}<0.05)$ effect in delaying ethylene production, color development and PME activity of tomato fruit.

Baldwin et al. (1999) evaluated the effect of two different edible coatings, one based on polysaccharides and the other based on carnauba wax, on the volatile content of mango fruit. Both edible coatings decreased fruit deterioration, although the polysaccharide coating increased the ethanol and acetaldehyde contents compared to the carnauba wax coating and control fruits. This increase in off-flavor compounds was attributed to the low permeability of the edible coating used (Baldwin et al., 1999). According to the sensory evaluation results obtained by the lab group, it appears that those levels were not sufficient to produce offflavors that could affect the acceptability of the product. It has been reported that edible coating treatments increase volatile concentrations in fruits due to the formation of a semi-permeable barrier ( Baldwin et al., 1999; Olivas and Barbosa-Canovas, 2005). However, the material and concentration used to produce the edible coatings can affect their performance and functionality.

\section{CONCLUSION}

The present study showed that coatings were effective in preserving the overall quality of tomato fruit. The use of a mineral oil treatment preserved the quality of tomato fruit to the greatest extent. In conclusion, mineral oil wax could be a good alternative for preserving the quality and extending the shelf life of fresh tomato fruit.

\section{ACKNOWLEDGEMENT}

We thanks to CIAD-CONACYT for financial support. This study is part of the $\mathrm{PhD}$ thesis of Dávila-Aviña.

\section{REFERENCES}

Alexander, L. and D. Grierson, 2002. Ethylene biosynthesis and action in tomato: A model for climacteric fruit ripening. J. Experimental Botany, 53: 2039-2055. DOI: 10.1093/jxb/erf072
Alonso, A., S. Garcia-Martinez, L. Vazquez-Araujo, J.J. Ruiz and A.A. Carbonell-Barrachina, 2010. Comparative post-harvest behaviour of traditional and virus-resistant Muchamiel tomatoes. J. Sci. Food Agric., 90: 1056-1062. DOI: 10.1002/jsfa. 3920

Baldwin, E.A., J.K. Burns, W. Kazokas, J.K. Brecht and R.D. Hagenmaier et al., 1999. Effect of two edible coatings with different permeability characteristics on mango (Mangifera indica L.) ripening during storage. Postharvest Biology Technol., 17: 215-226. DOI: 10.1016/S09255214(99)00053-8

Batu, A., 2004. Determination of acceptable firmness and colour values of tomatoes. J. Food Eng., 61: 471-475. DOI: 10.1016/S0260-8774(03)00141-9

Brooks, M.S., N.H.A. El-Hana and A.E. Ghaly, 2008. Effects of tomato geometries and air temperature on the drying behavior of plum tomato. Am. J. Applied Sci., 5: 1369-1375. DOI: 10.3844/ajassp.2008.1369.1375

Brummell, D.A. and M.H. Harpster, 2001. Cell wall metabolism in fruit softening and quality and its manipulation in transgenic plants. Plant Molecular Biology, 47: 311-339. DOI: 10.1023/A:1010656104304

Chumarrelli, M. and M.D. Ferreira, 2006. Qualidade pós-colheita de tomates 'Débora' com utilização de diferentes coberturas comestiveis e temperaturas de armazenamento. Horticultura Brasileira, 24: 381-385. DOI: $10.1590 / \mathrm{S} 0102-05362006000300023$

El Ghaouth, A., J. Arul, J. Grenier and A. Asselin, 1992. Chitosan coating to extend the storage life of tomatoes. Hortscience, 27: 1016-1018. http://library.wur.n1/WebQuery/titel/820136

Espino-Diaz, M., J.J. Ornelas-Paz, M.A. Martinez-Téllez, C. Santillan and G. Barbosa-Canovas et al., 2010. Development and characterization of edible films based on mucilage of Opuntia ficus-indica (L.). J. Food Sci., 75: 347-352. DOI: 10.1111/j.17503841.2010.01661.x

Gayosso-Garcia, S.L.E., E. M.Yahia, M.A. MartínezTéllez, G.A. González-Aguilar, 2010. Effect of maturity stage of papaya maradol on physiological and biochemical parameters. Am. J. Agri. Biol. Sci., 5: 194-203. 10.3844/ajabssp.2010.194.203

Gonzalez-Aguilar, G., J. Ayala-Zavala, G. Olivas, L. de la Rosa and E. Alvarez-Parrilla, 2010a. Preserving quality of fresh-cut products using safe technologies. J. Für Verbraucherschutz und Lebensmittelsicherheit, 5: 65-72. DOI: 10.1007/s00003-009-0315-6 
Gonzalez-Aguilar, G.A., J.F. Ayala-Zavala, L.A. de la Rosa and E. Alvarez-Parrilla, 2010b. Phytochemical Changes in the Postharvest and Minimal Processing of Fresh Fruits and Vegetables. In: Fruit and Vegetable Phytochemicals: Chemistry, Nutritional Value and Stability, De la Rosa, L.A., E. Alvarez-Parrilla and G.A. Gonzalez-Aguilar (Eds.). Wiley-Blackwell, Ames, USA., ISBN: 9780-8138-0320-3, pp: 309-340.

Gonzalez-Aguilar, G.A., E. Valenzuela-Soto, J. LizardiMendoza, F. Goycoolea and M.A. Martinez-Téllez et al., 2009. Effect of chitosan coating in preventing deterioration and preserving the quality of fresh-cut papaya 'Maradol. J. Sci. Food Agric., 89: 15-23. DOI: 10.1002/jsfa.3405

Gonzalez-Aguilar, G.A., J. Celis, R.R. Sotelo-Mundo, L.A. de la Rosa and J. Rodrigo-Garcia et al., 2008. Physiological and biochemical changes of different fresh-cut mango cultivars stored at $5{ }^{\circ} \mathrm{C}$. Int. J. Food Sci. Technol., 43: 91-101. DOI: 10.1111/j.1365-2621.2006.01394.x

Gonzalez-Aguilar, G.A., J.F. Ayala-Zavala, S. RuizCruz, E. Acedo-Felix and M.E. Diaz-Cinco, 2004. Effect of temperature and modified atmosphere packaging on overall quality of fresh-cut bell peppers. LWT Food Sci. Technol., 37: 817-826. DOI: $10.1016 /$ j.lwt.2004.03.007

Hernandez, S.M., E. Rodriguez Rodriguez and C. Diaz Romero, 2008a. Analysis of organic acid content in cultivars of tomato harvested in Tenerife. Eur. Food Res. Technol., 226: 423-435. DOI: 10.1007/s00217-006-0553-0

Hernandez, S.M., E.M. Rodriguez Rodriguez and C. Diaz Romero, 2008b. Chemical composition of tomato (Lycopersicon esculentum) from Tenerife, the Canary Islands. Food Chem., 106: 1046-1056. DOI: 10.1016/j.foodchem.2007.07.025

Islas-Osuna, M.A., N.A. Stephens-Camacho, C.A. ContrerasVergara, M. Rivera-Dominguez and M.A. VillegasOchoa et al., 2010. Novel postharvest treatment reduces ascorbic acid losses in mango (Mangifera indica L.) Var. Kent. Am. J. Agri. Biol. Sci., 5: 342-349. DOI: 10.3844/ajabssp.2010.342.349

Mejia-Torres, S., M. Vega-Garcia, J. Valverde-Juarez, J. Lopez-Valenzuela and J. Caro-Corrales, 2009. Effect of Wax application on the quality, Lycopene content and chilling injury of tomato fruit. J. Food Qua., 32: 735-746. DOI: 10.1111/j.17454557.2009.00284. $\mathrm{x}$

Olivas, G.I. and G.V. Barbosa-Canovas, 2008. Alginate-calcium films: Water vapor permeability and mechanical properties as affected by plasticizer and relative humidity. LWT Food Sci. Technol., 41: 359-366. DOI: 10.1016/j.lwt.2007.02.015
Olivas, G.I., J.E. Davila-Avina, N.A. Salas-Salazar and F.J. Molina, 2008. Use of edible coatings to preserve the quality of fruits and vegetables during storage. Stewart Postharvest Rev., 4: 1-9. DOI: 10.2212/spr.2008.3.6

Olivas, G. I. and G.V. Barbosa-Canovas, 2005. Edible coatings for fresh-cut fruits. Crit. Rev. Food Sci. Nutr., 45: 657-670. DOI: $10.1080 / 10408690490911837$

Olivas, G.I., J.J. Rodriguez and G.V. Barbosa-Canovas, 2003. Edible coatings composed of methylcellulose, stearic acid, and additives to preserve quality of pear wedges. J. Food Proc. Pres., 27: 299-320. DOI: 10.1111/j.17454549.2003.tb00519.x

Park, H.J., M.S. Chinnan, R.L. Shewfelt, 1994. Edible coating effects on storage life and quality of tomatoes. J. Food Sci., 59: 568-570. DOI: $10.1111 / \mathrm{j} .1365-2621.1994 . t b 05563 . x$

Perez-Gago, M.B., G.A. Gonzalez-Aguilar and G.I. Olivas, 2010. Edible coatings for fruits and vegetables. Stewart Postharvest Rev., 6: 1-14. DOI: 10.2212/spr.2010.3.4

Pek, Z., L. Helyes and A. Lugasi, 2010. Color changes and antioxidant content of vine and postharvestripened tomato fruits. Hortscience, 45: 466-468. Raffo, A., C. Leonardi, V. Fogliano, P. Ambrosino and M. Salucci et al., 2002. Nutritional value of cherry tomatoes (Lycopersicon esculentum $\mathrm{Cv}$. Naomi F1) harvested at different ripening stages. J. Agric. Food Chem., 50: 6550-6556. DOI: 10.1021/jf020315t

Reddy, M.V.B., P. Angers, F. Castaigne and J. Arul, 2000. Chitosan effects on blackmold rot and pathogenic factors produced by Alternaria alternata in postharvest tomatoes. J. Am. Soc. Horticultural Sci., 125: 742-747.

Rojas-Graü, M.A., G. Oms-Oliu, R. Soliva-Fortuny and O. Martin-Belloso, 2009. The use of packaging techniques to maintain freshness in fresh-cut fruits and vegetables: a review. Int. J. Food Sci. Technol., 44: 875-889. DOI: $10.1111 /$ j.13652621.2009.01911.x

Sargent, S.A., J.K. Brecht and T. Olczyk, 2005. Handling Florida Vegetables Series - Round and Roma Tomato Types. University of Florida IFAS Extensión. http://edis.ifas.ufl.edu/pdffiles/VH/VH07900.pdf

Tasdelen, O. and L. Bayindirli, 1998. Controlled atmosphere storage and edible coating effects on storage life and quality of tomatoes. J. Food Proc. Pres., 22: 303-320. DOI: 10.1111/j.17454549.1998.tb00352.x 
Zapata, P.J., F. Guillen, D. Martinez-Romero, S. Castillo and D. Valero et al., 2008. Use of alginate or zein as edible coatings to delay postharvest ripening process and to maintain tomato (Solanum lycopersicon Mill) quality. J. Sci. Food Agric., 88: 1287-1293. DOI: $10.1002 /$ jsfa.3220
Zhuang, R.Y. and Y.M. Huang, 2003. Influence of hydroxypropyl methylcellulose edible coating on fresh-keeping and storability of tomato. J. Zhejiang Univ. Sci., 4: 109-113. DOI: 10.1007/BF02841088 